\title{
Stosunki polsko-ukraińskie w polityce (dez)informacyjnej Federacji Rosyjskiej
}

„Nie trzeba już bombardować miast. Wystarczy zbombardować mózgi”. Oksana Zabużko ${ }^{1}$

$\mathrm{N}$ iniejszy tekst jest próbą zwięzłego i syntetycznego przedstawienia cech charakterystycznych i uwarunkowań polityki informacyjnej Federacji Rosyjskiej w odniesieniu do stosunków Polski i Ukrainy. Należy przy tym zaznaczyć, że polityka ta jest elementem szerszej strategii Rosji, zmierzającej do odbudowania i utrzymania pozycji mocarstwowej.

\section{Strategiczne cele Rosji i rola działań w sferze informacyjnej}

Strategia odzyskania pozycji mocarstwowej jest realizowana konsekwentnie od chwili objęcia władzy przez prezydenta Władimira Putina i skupiona wokół niego elity władzy² - w dużej mierze wywodząca się zresztą ze struktur siłowych. W szerszym kontekście, odnoszącym się do kształtu ładu międzynarodowego, celem jest nie tyle pozycja mocarstwowa jako taka, ale ugruntowanie jej przez przekształcenie obecnego, w dużej mierze zinstytucjonalizowanego i liberalnego porządku międzynarodowego w taki sposób, by dominująca rola przypadła ograniczonej grupie mocarstw, w tym przypadku Rosji. Tym samym byłby to powrót do swoistego „koncertu mocarstw”. By zrealizować ten cel, Rosja prowadzi działania, które są zróżnicowane nie tylko pod względem różnorodności stosowanych metod i instrumentów, lecz także jeśli chodzi o kierunki i „adresatów”.

W odniesieniu do obszaru byłego Związku Radzieckiego są to działania zmierzające do utrzymania państw istniejących dziś na tym obszarze w sferze wpływów Rosji,

1 https://apostrophe.ua/article/society/culture/2017-04-18/oksana-zabujko-segodnya-ne-nujnobombit-goroda-dostatochno-razbombit-mozgi/11737

2 Jest to uproszczenie - rosyjskie elity władzy nie są jednorodne i spójne, proces ich różnicowania i narastania napięć wewnętrznych widocznie ostatnio przybiera na sile. 
ograniczenia w tych państwach wpływów zachodnich czy wreszcie wprost uzależnienia (ekonomicznego, kulturowego, surowcowego, militarnego) części obszaru poradzieckiego od Rosji ${ }^{3}$. W przypadku Zachodu, utożsamianego w dużej mierze z głównymi instytucjami świata zachodniego, tj. Unią Europejską i NATO, a postrzeganego jako najistotniejszy antagonista Rosji, strategicznym celem jest rozbicie jedności - osłabienie tych instytucji, więzi transatlantyckich i doprowadzenie do sytuacji, w której spójna postawa i polityka Zachodu zostanie zastąpiona przez partykularnie artykułowane interesy poszczególnych państw. Tego rodzaju osłabienie politycznej przestrzeni euroatlantyckiej, prowadzące jednocześnie do marginalizacji państw średnich i małych, pozwoliłoby Rosji na prowadzenie polityki intensyfikacji relacji z najważniejszymi graczami - „ponad głowami” pozostałych, zmarginalizowanych państw. Konsekwencją byłaby wzmiankowana rekonstrukcja ładu międzynarodowego, z korzyścią dla pozycji i roli Rosji.

Strategia taka nie jest novum w historii Rosji i jej polityki międzynarodowej. Dążenie do zapewnienia sobie bezpieczeństwa przez ekspansję, utrzymywanie statusu mocarstwa, myślenie w kategoriach siły oraz konsekwentne stosowanie zasady divide et impera są głęboko zakorzenione w rosyjskiej kulturze strategicznej ${ }^{4}$. Dotyczy to także specyficznej, „imperialnej mentalności” (co, gwoli ścisłości, nie jest charakterystyczne jedynie dla Rosji).Z kolei postępujący proces globalizacji gospodarki światowej i wzrost zapotrzebowania na surowce energetyczne skutkuje de facto sekurytyzacją tego sektora gospodarki ${ }^{5}$. Wykorzystywanie działań w sferze informacyjnej czy instrumentów wpływu kulturowego także nie jest zjawiskiem nowym (w Związku Radzieckim prowadzono szeroko zakrojone działania w sferze manipulacji społecznej). Należy jednak wyraźnie zaznaczyć, że nigdy wcześniej tego typu instrumenty nie były wykorzystywane na tak dużą skalę jak obecnie. Wynika to przede wszystkim z rewolucji technologicznej, która umożliwiła bezprecedensowy skok jakościowy. Nowoczesne technologie informacyjne, media elektroniczne, sieci społecznościowe i ich rosnący wpływ na funkcjonowanie społeczeństw ${ }^{6}$ umożliwiają wpływanie na „rząd dusz”, kształtowanie opinii publicznej i decyzji politycznych na skalę globalną - pod warunkiem posiadania odpowiedniego know how, woli politycznej, zasobów i narzędzi. Odwołując się do znanej koncepcji „fal

3 Przy czym trzeba pamiętać, że w strategii Rosji poszczególne części tego obszaru mają różne znaczenie i różna polityka jest realizowana w odniesieniu do nich. Zob. A. Włodkowska-Bagan, Polityka Rosji na obszarze poradzieckim, „Wschodni Rocznik Humanistyczny” 2017, t. 14, nr 3, s. 66-68.

4 Zob. szerzej: ead, Kultura strategiczna Rosji, „Sprawy Międzynarodowe” 2017, nr 3, s. 36-47.

5 Strategiczne znaczenie surowców energetycznych doceniano już w Związku Radzieckim i to w dużej mierze dzięki sektorowi energetycznemu; w szczególnie trudnych latach 1991/92 gospodarka Rosji nie załamała się całkowicie. Natomiast w relacjach z Ukrainą wielokrotnie pojawiały się spory i konflikty odnoszące się do warunków handlu gazem i jego ceny; doszło nawet do tzw. „wojny gazowej" (2005-2008). Zob. szerzej na temat historii Gazpromu: W. Paniuszkin, M. Zygar, Gazprom. Rosyjska broń, Warszawa 2008.

6 O czym pisał Manuel Castells już w 1996 r. Zob. M. Castells, Społeczeństwo sieci, Warszawa 2007, s. 351-380. 
cywilizacyjnych", autorstwa Heidi i Alvina Tofflerów, można stwierdzić - dokonując co prawda pewnego uproszczenia - że w erze agrarnej ludzie walczyli ze sobą przy użyciu mięśni, w erze industrialnej przy użyciu wytwarzanych przez siebie maszyn, w erze informacyjnej natomiast - przy użyciu informacji. Posługiwanie się informacją (i dezinformacją) umożliwia manipulację, ułatwiającą z kolei realizację własnych celów, także politycznych, tj. skłanianie jednostek i grup do myślenia/działania w sposób pożądany z punktu widzenia podmiotu tą informacją/dezinformacją się posługującego. Szczególnego znaczenia nabiera to $\mathrm{w}$ sytuacji, kiedy każdy może być jednocześnie nadawcą i odbiorcą informacji, a szum informacyjny wynikający z wielości zarówno istniejących kanałów przepływu informacji, jak i treści w istotny sposób utrudnia bądź wręcz uniemożliwia selekcję docierającej informacji pod kątem rzetelności i zgodności z faktami (co dodatkowo jest wzmacniane błędami kognitywnymi) ${ }^{7}$.

Rosja dysponuje zarówno wolą polityczną, jak i zasobami oraz narzędziami. Ponadto rosyjscy decydenci zdają sobie sprawę z tego, że biorąc pod uwagę różnicę potencjałów między Rosją a Zachodem, by realizować swoje cele strategiczne, należy sięgać nie tylko po „twarde” instrumenty rywalizacji (surowcowo-energetyczne, militarne itp.), ale także po instrumenty „miękkie”, tj. zasoby soft power, wpływy kulturowe (stąd np. koncepcja russkogo mira) czy zróżnicowane oddziaływania w sferze informacyjnej, łatwo przenikające przez granice. Zwłaszcza że w odniesieniu do działań tego rodzaju, prowadzonych wobec Zachodu, Rosja ma przewagę wynikającą z asymetrii - państwa zachodnie, ze swoją liberalną demokracją, pluralizmem opinii, wolnością słowa i mediów nie mogą w sferze informacyjnej skutecznie konkurować z Rosją. Przewagę tę daje Rosji faktyczne podporząakowanie państwu największych mediów, ale przede wszystkim stworzenie rozbudowanej machiny dezinformacyjno-propagandowej i konsekwentne oraz umiejętne jej używanie do realizacji celów politycznych, tak w odniesieniu do własnego społeczeństwa, jak i środowiska zewnętrznego. Nie są to także działania doraźne i improwizowane, lecz uzupełniające działania w innych wymiarach i wpisujące się w ogólną strategię Rosji - zgodnie z założeniem, że zwycięstwo w konfrontacji informacyjnej przełoży się na realizację celów strategicznych i politycznych ${ }^{8}$. Intensyfikacja rosyjskiej aktywności w infosferze, widoczna w ostatnich latach szczególnie po aneksji Krymu i wybuchu konfliktu na Donbasie, nie oznacza jednak, że działania tego rodzaju nie były prowadzone wcześniej. Wypracowana przez Jewgienija Messnera kilkadziesiąt lat temu koncepcja „wojen buntowniczych” (мятежвойны)

Jednym z efektów jest powstawanie tzw. baniek informacyjnych - ludzie skłaniają się ku korzystaniu z tych źródeł informacji, do których już przywykli i które prezentują treści zgodne z poglądami danej grupy odbiorców. Tym samym, przyjmując ich narracje i punkty widzenia, wzmacniane przez intensywność przekazu, utwierdzają się w swoich przekonaniach, jednocześnie odrzucając inne punkty widzenia. Szczególną formą jest tzw. bańka filtrująca - media społecznościowe czy wyszukiwarki internetowe stosują algorytmy, które dostarczają użytkownikom treści podobnych do tych, którymi wcześniej wykazali zainteresowanie czy które są zgodne z ich poglądami. Zob. szerzej: E. Pariser, The Filter Bubble: What The Internet is Hiding from You, London 2012.

8 Por. K. Giles, Handbook of Russian information warfare, Rome 2016, p. 17-21. 
została zmodyfikowana i wzbogacona o nowe elementy, oparte na technologiach informacyjnych, stając się fundamentem dzisiejszej „wojny hybrydowej”, prowadzonej przez Rosję. Zdaniem wielu ekspertów te hybrydowe działania Rosji wobec Ukrainy rozpoczęły się już kilkanaście lat temu, kiedy wydarzenia pomarańczowej rewolucji uzmysłowiły władzom rosyjskim, że utrzymanie Ukrainy w rosyjskiej strefie wpływów nie będzie procesem łatwym i szybkim do zrealizowania, a "geopolityka informacyjna" Rosji zaczęła być rozwijana już w latach 90. ubiegłego stulecia9. Słuszności tej tezy dowodzić może przebieg aneksji Półwyspu Krymskiego - zajęcie go w 2014 roku było poprzedzone wieloletnimi działaniami w różnych sferach, także informacyjnej, skierowanymi do ludności półwyspu. W efekcie sama operacja zajęcia terytorium dokonała się błyskawicznie - kluczową rolę odegrał czynnik psychologiczny (nastawienie większości miejscowej ludności, a nawet części ukraińskiego personelu wojskowego). Aneksja Krymu ukazała, jaką rolę odgrywa dziś infosfera i działania skierowane na kształtowanie morale i przekonań społeczeństwa. Warto podkreślić, że mimo rosnącej w ostatnim czasie popularności geopolityki (jako uniwersalnego narzędzia, wyjaśniającego całokształt stosunków międzynarodowych) oraz renesansu myślenia w kategoriach realizmu politycznego (lub neorealizmu) nie brakuje i w środowiskach politycznych, i eksperckich, faworyzujących te „twarde” paradygmaty opinii, że „współcześnie klasyczna geopolityka zmienia się w geopolitykę informacyjną", a „wiodącą formą realizacji celów politycznych staje się wojna informacyjna"10.

\section{Zróżnicowanie działań (dez)informacyjnych Rosji}

Działania w sferze informacyjnej, odnoszące się do Polski, Ukrainy i relacji między nimi to, jak wspomniano, jeden z wielu kierunków tego rodzaju działań, prowadzonych przez Rosję. W zależności od podmiotu-„,adresata” działania te są różnicowane pod względem treści, metod i form przekazu. I tak na przykład w przypadku państw bałtyckich jako narzędzie nacisku wykorzystywano, liczną tam, mniejszość rosyjską (w przypadku Litwy także polską). Sama jej obecność przekłada się na wpływy polityczne Rosji, natomiast w połączeniu z rosyjskimi deklaracjami o „ochronie” Rosjan mieszkających poza granicami Federacji Rosyjskiej i siłą rosyjskojęzycznych mediów $\mathrm{w}$ tym regionie generuje to poczucie zagrożenia i niepewności ${ }^{11}$. W efekcie wszystkie trzy państwa bałtyckie zwiększają wydatki na obronność i przykładają coraz większą wagę do kwestii zagrożeń hybrydowych i asymetrycznych, w tym płynących z cyberprzestrzeni (wciąż mając w pamięci rosyjskie cyberataki w Estonii w 2007 roku). Także

9 Zob. np. Є. Магда, Гібридна війна. Вижити і перемогти, Харків 2015; J. Darczewska, Anatomia rosyjskiej wojny informacyjnej. Operacja krymska - studium przypadku, „Punkt Widzenia OSW” 2014, $\mathrm{nr} 42$.

10 L. Sykulski, Rosyjska koncepcja wojen buntowniczych Jewgienija Messnera, „Przegląd Geopolityczny” 2015, t. 11, s. 111.

11 W 2015 r. Ministerstwo Obrony Narodowej Litwy opublikowało obszerną broszurę informacyjną dla obywateli, zawierającą instrukcje dotyczące zachowania się w przypadkach różnych zagrożeń (agresja obcych sił zbrojnych, atak chemiczny itp.), gromadzenia zapasów, ewakuacji. 
NATO ma świadomość złożonej sytuacji na tym obszarze, nie tylko w wymiarze militarnym (stąd obecność sił zbrojnych sojuszu), ale i informacyjnym (nieprzypadkowe ulokowanie w Rydze natowskiego centrum komunikacji strategicznej - NATO Strategic Communications Centre of Excellence).

$\mathrm{Na}$ Bałkanach Zachodnich głównym celem Rosji jest utrzymanie tego regionu, w miarę możliwości, w sferze własnych wpływów i niedopuszczenie do zbliżenia państw regionu z zachodnimi strukturami politycznymi. Stąd nacisk, w płaszczyźnie informacyjnej, na wspólnotę kulturową Słowian prawosławnych czy na podkreślanie agresywnego i ekspansywnego charakteru NATO. O ile w przypadku Serbii retoryka ta jest wciąż skuteczna, o tyle przypadek Czarnogóry okazał się dla Rosji porażką mimo głębokiej penetracji przez rosyjski kapitał i znacznych wpływów politycznych Czarnogóra została w 2017 roku państwem członkowskim NATO. Rosja przyjęła to z głębokim niezadowoleniem, które może się jeszcze pogłębić, biorąc pod uwagę, że do NATO aspirują także Macedonia oraz Bośnia i Hercegowina. Najprawdopodobniej więc spowoduje to nasilenie rosyjskich działań w infosferze Bałkanów Zachodnich.

Istotniejsze jednak z punktu widzenia Rosji są państwa Europy Zachodniej. Im stabilniejsza i silniejsza Europa, tym bardziej stoi to w sprzeczności z interesami Rosji. Zatem celem Rosji jest inspirowanie i podsycanie konfliktów społecznych wokół napięć i problemów, zarówno tych rzeczywistych, jak i tych sztucznie stwarzanych. Dotyczy to także osłabiania relacji transatlantyckich przez wspieranie nastrojów i retoryki antyamerykańskiej. W kontekście relacji międzynarodowych odnosi się to też do podgrzewania sporów historycznych między poszczególnymi państwami i narodami.

Sporów tego rodzaju nie brakuje w Europie Środkowo-Wschodniej, obszarze istotnym dla Rosji z kilku powodów. Po pierwsze, to swoista strefa buforowa między Rosją a „starą Europą". Po drugie, państwa regionu podejmują inicjatywy (z różną jak na razie efektywnością), mające zmierzać do zacieśniania współpracy - a taki scenariusz byłby niekorzystny dla Rosji. Po trzecie, w Europie Środkowo-Wschodniej coraz bardziej obecne są wojskowo Stany Zjednoczone Ameryki. Po czwarte, obszar ten jest niezmiennie istotny $\mathrm{z}$ racji rozbudowanych zależności energetycznych, $\mathrm{w}$ tym także uzależnienia $\mathrm{w}$ tym wymiarze od Rosji. Zatem $\mathrm{w}$ jej interesie jest to, by państwa tego regionu były niestabilne, a najlepiej niechętnie ze sobą współpracujące (w myśl zasady divide et impera). Relacje polsko-ukraińskie są elementem szerszego układu sił i zależności, obejmującego cały region środkowoeuropejski, ale także ważnym czynnikiem porządku międzynarodowego w Europie. Dobre i bliskie relacje Polski i Ukrainy to wyzwanie dla mocarstwowych aspiracji Rosji, ale też zbliżenie, w szerszym wymiarze, Ukrainy z Zachodem. Z perspektywy Ukrainy Polska jest „najbliższym Zachodem” czy „bramą na Zachód”. Z perspektywy prozachodnich aspiracji Ukrainy Polska nie ma wprawdzie, $\mathrm{z}$ różnych powodów, znaczenia kluczowego (bo to przypada takim graczom, jak Niemcy, Francja czy Stany Zjednoczone Ameryki), niemniej jednak im lepsze stosunki polsko-ukraińskie, tym lepsze relacje na linii Ukraina-Zachód i tym dalej Ukraina od rosyjskiej strefy wpływów i tym większa determinacja Rosji, by te relacje uczynić jak najgorszymi. 
W związku z powyższym wiele podejmowanych przez Rosję działań zmierza do wpływania na stosunki polsko-ukraińskie i kształtowania ich zgodnie z interesami Rosji. W prowadzonych obecnie działaniach $\mathrm{w}$ sferze informacyjnej (notabene nie tylko przez Rosję i nie tylko w wymiarze międzynarodowym) zasadniczą metodą jest rozpowszechnianie narracji kształtującej pożądany obraz świata. Sprzyja temu penetrowanie środowisk opiniotwórczych - politycznych, dziennikarskich, akademickich. W kontekście stosunków polsko-ukraińskich skuteczność tej penetracji jest możliwa dzięki wykorzystaniu sympatii prorosyjskich i postaw antyukraińskich, obecnych w różnym zakresie i z różnym natężeniem w wielu środowiskach w Polsce. Jednocześnie w społeczeństwie ukraińskim obecne są resentymenty i stereotypy w stosunku do Polski i Polaków, zakorzenione w doświadczeniach historycznych, a kształtowane nierzadko jeszcze w okresie istnienia Związku Radzieckiego. Prawdopodobnie jednak, bez propagandowego wzmocnienia, jakie obecnie się pojawia, te uprzedzenia i stereotypy nie odgrywałyby znaczącej roli w kształtowaniu stosunków między Ukrainą a Polską.

W narracji rosyjskiej (tudzież prorosyjskiej) Polska i Ukraina są sobie przeciwstawiane i przedstawiane jako wrogowie i wzajemne zagrożenie dla siebie. Celem jest również wzmacnianie nastrojów prorosyjskich tak na Ukrainie, jak i w Polsce, a także podsycanie sporów wewnętrznych i pogłębianie polaryzacji społeczeństw polskiego i ukraińskiego ${ }^{12}$. Zastosowanie znajdują tu różnorodne i liczne instrumenty. Są wśród nich oficjalne media: kanały telewizji publicznej (adresowane głównie do wewnątrz - większość Rosjan czerpie wiedzę o świecie z telewizji), rozszerzająca swoje wpływy w świecie telewizja RT czy agencja informacyjna Sputnik. Inny efektywny instrument to liczne portale internetowe, które często podkreślają swoją „niezależność” przez nazywanie się „wolnymi”, „niepokornymi”, „patriotycznymi” itp. oraz odcinają od „mediów głównego nurtu", sugerując tym samym, że to właśnie "główny nurt” okłamuje obywateli i nimi manipuluje. Portale tego rodzaju w sposób zakamuflowany lub otwarty prezentują rosyjską (czy raczej: kremlowską) wizję rzeczywistości i zazwyczaj, dla uwiarygodnienia, starają się wyglądać nie jak platformy mające kształtować określone opinie i poglądy, ale jak klasyczne portale informacyjne, którymi w istocie nie są. Do lansowania i rozpowszechniania rosyjskich narracji służą też sieci społecznościowe, tu z kolei są zazwyczaj używane boty oraz użytkownicy, których zadaniem jest upowszechnianie określonych treści (tzw. trolle internetowe), także przy użyciu wielu fałszywych kont. Wreszcie rolę nośnika przekazów, które odpowiadają interesom Rosji, pełnią wzmiankowane już środowiska opiniotwórcze - w wielu wypadkach czyniąc to zresztą albo cynicznie (np. by zrealizować dzięki temu własne interesy polityczne), albo nieświadomie - we własnym przekonaniu działając w interesie własnego państwa, środowiska lub „prawdy historycznej”. Przydatni są także zwolennicy różnorodnych

$12 \mathrm{~W}$ odniesieniu do Polski ciekawym przykładem jest kwestia wraku prezydenckiego Tupolewa Tu-154, od 2010 r. pozostającego w Rosji, która nie kwapi się z jego zwrotem Polsce. Władze rosyjskie zdają sobie bowiem sprawę z tego, że dopóki wrak jest w Rosji, w Polsce sprawa katastrofy smoleńskiej będzie stale powracała i powodowała emocje i podziały w społeczeństwie. 
teorii spiskowych, które zresztą bywają wplatane w rosyjską narrację i pojawiają się na „niezależnych” portalach (co ma potęgować chaos informacyjny i dodatkowo utrudniać selekcję informacji, a więc uwiarygodniać dezinformację). Trzeba także pamiętać, że Rosja stworzyła całą sieć państwowych instytucji, których celem jest promocja Rosji i jej interesów na świecie - przy pomocy wszelkich instrumentów ${ }^{13}$.

Cele tych działań także są zróżnicowane. W wymiarze politycznym oddziaływania w infosferze mogą być użyte do wpływania na wyniki wyborów, a w wymiarze ekonomicznym do tworzenia infrastruktury biznesowej sprzyjającej Rosji. Najogólniej, na dłuższą metę, celem jest manipulowanie opinią publiczną (i decydentami) i destabilizowanie sytuacji politycznej i społecznej, czyli generowanie chaosu ${ }^{14}$ (co w dalszej perspektywie może pozwolić na realizację konkretnych celów w różnych płaszczyznach).

\section{Narracje antypolskie i antyukraińskie w polityce informacyjnej Rosji}

Narracje rosyjskie, adresowane do Polaków i Ukraińców, w większości elementów są „sformatowane”, czyli dopasowane do odbiorców. Przekaz pojawiający się w Polsce w niektórych wątkach jest zbieżny z ogólną narracją, adresowaną do Zachodu: w tym przekazie Ukraina jest prezentowana jako państwo upadłe, a przynajmniej właśnie upadające. Jest też rządzona raczej przez nieformalne sieci oligarchiczne niż nieefektywne instytucje państwowe, głęboko zdestabilizowana i w istocie w sposób instrumentalny używana przez Stany Zjednoczone (oraz Izrael) do prowokowania Rosji ${ }^{15}$. Jako państwo upadłe i nieefektywne, a w gruncie rzeczy sztuczne i pozbawione tradycji, historii oraz tożsamości, Ukraina mogłaby właściwie zostać podzielona między Rosję, Polskę, Węgry i Rumunię - propozycja taka (najprawdopodobniej świadoma prowokacja), sformułowana publicznie przez Władymira Żyrinowskiego w 2014 roku, podchwycona została w Polsce przez różne środowiska, zwłaszcza narodowe i „kresowe”, pielęgnujące koncepcję „odzyskania Lwowa”. Według innego wątku rosyjskiej narracji o Ukrainie, po 2013 roku i wydarzeniach „Euromajdanu” Ukraina stała się niedemokratycznym reżimem, który szczególnie w okresie trwania „Euromajdanu”, aneksji Krymu i inten-

13 Zob. szerzej: K. Smagliy, Hybrid Analytica: Pro-Kremlin Expert Propaganda in Moscow, Europe and the US, Institute of Modern Russia Research Paper, October 2018, New York.

14 Działania, których celem jest „sianie zamętu”, ale też, w określonych wypadkach, testowanie zdolności mobilizacji i reakcji, przybierają bardzo różnorodne formy. Np. po incydencie na Morzu Azowskim i wprowadzeniu na Ukrainie stanu wojennego (2018 r.) mieszkańcy niektórych gmin na wschodzie Polski otrzymali SMS-y, rzekomo z Rządowego Centrum Bezpieczeństwa, wzywające mężczyzn do stawienia się w urzędach gmin „w związku z sytuacją kryzysową na Ukrainie”. Jednocześnie podobna sytuacja miała miejsce po ukraińskiej stronie granicy. Kimkolwiek byli sprawcy, ich celem mogło być testowanie możliwości reakcji struktur państwowych i społeczeństwa, udało im się zasiać niepokój i zamieszanie, pokazali też, że dysponują technicznymi możliwościami dotarcia do telefonicznego skontaktowania się z mieszkańcami wybranych, określonych obszarów. RCB rozesłało alert informujący, że „wezwanie” było fałszywe, dopiero 20 godzin po wyznaczonej w SMS-ie godzinie stawienia się w urzędach.

15 Co doprowadzi, już wkrótce, do wybuchu wojny światowej i przekształcenia porządku międzynarodowego - taka wizja staje się coraz bardziej popularna. 
sywnych walk na Donbasie nazywany był wprost reżimem faszystowskim (w nawiązaniu do kolaboracji części środowisk ukraińskich z III Rzeszą - choć kolaboracja była w rzeczywistości znacznie bardziej rozwinięta w przypadku Rosjan niż Ukraińców).

Określenie „faszyzm” pojawia się obecnie w rosyjskiej narracji w kontekście Ukrainy i w inspirowanych nią treściach rzadko, natomiast rolę słowa-klucza przejęło określenie „banderowcy”. Stiepan Bandera i UPA są utożsamiani z obecną Ukrainą (określaną mianem „Upainy”) i Ukraińcami - jest to daleko idące nadużycie, ponieważ S. Bandera nigdy nie był i nie jest powszechnie uważany na Ukrainie za bohatera (w istocie zresztą nie zasłużył się niczym nadzwyczajnym, w przeciwieństwie choćby do Semena Petlury). Narracja ta jest jednak intensywnie eksploatowana, ponieważ to właśnie w Polsce, $\mathrm{z}$ racji żywej pamięci o zbrodniach popełnionych przez UPA na Polakach, określenie „banderowiec" jest szczególnie nacechowane emocjonalnie i łatwo wywołuje reakcje, nierzadko gwałtowne. UPA i Bandera byli zresztą negatywnymi postaciami przez cały okres powojenny - Związek Radziecki zwalczał intensywnie jakąkolwiek ideę „ukraińskości” (uderzała bowiem w jedność ZSRR i zagrażała dominującej roli Rosjan w imperium sowieckim) i każdego, kto posługiwał się językiem ukraińskim czy wspominał o tożsamościowej odrębności Ukrainy, nazywał „banderowcem”, wcieleniem wszelkiego zła. Taką samą politykę prowadziły więc ówczesne władze Polski. W rezultacie utrwalił się wizerunek „Ukraińca-banderowca-rezuna”, dziś wykorzystywany sprawnie przez Rosję.

Kolejny wątek antyukraińskiej narracji, inspirowanej przez Rosję i prorosyjskie środowiska, pojawił się wraz ze wzrostem liczby imigrantów zarobkowych z Ukrainy, przybywających do Polski. Spośród wszystkich państw Unii Europejskiej to właśnie Polska jest najczęściej wybierana przez Ukraińców wyjeżdżających za granicę w poszukiwaniu pracy. Nie mogą oni liczyć w Polsce na wysokie zarobki, przyciąga ich jednak bliskość geograficzna, niskie koszty życia (w porównaniu z Europą Zachodnią) i stosunkowo liberalny system zatrudniania obywateli państw Partnerstwa Wschodniego, a pokrewieństwo kulturowe i językowe pozwala na łatwiejszą komunikację i adaptację. Ze względu na stale zmieniającą się liczbę przyjeżdżających i wyjeżdżających oraz skomplikowany polski system zbierania danych administracyjnych niełatwo oszacować liczbę Ukraińców przebywających jednocześnie w Polsce. Przyjąć jednak można, że jest to około 900 tysięcy $^{16}$. Jest to zatem grupa licząca się i zauważalna, co jednocześnie dostarcza pretekstu do ataków propagandowych. Jednym z wątków jest oskarżanie imigrantów z Ukrainy o „zabieranie pracy” (nawiasem mówiąc, analogiczny do oskarżeń wysuwanych np. w Wielkiej Brytanii wobec imigrantów zarobkowych z Polski). Biorąc pod uwagę koniunkturę gospodarczą i relatywnie dobrą sytuację na polskim rynku pracy, objawiającą się m.in. wzrostem zapotrzebowania na siłę roboczą, argument ten stał się jednak mało przekonujący. W jego miejsce pojawiają się więc fałszywe doniesienia, mówiące np. o rzekomych dodatkowych świadczeniach i przywilejach dla pracowników z Ukrainy, które to świadczenia są niedostępne dla polskich

16 Według raportu Ośrodka Studiów Wschodnich: M. Jaroszewicz, Migracje z Ukrainy do Polski. Stabilizacja trendu, Warszawa 2018, s. 5-7. 
pracowników. Tego rodzaju argumentacja koresponduje zresztą z szerszą narracją rosyjską, adresowaną do Europejczyków i odwołującą się do obaw społeczeństw europejskich przed imigrantami i uchodźcami. Natomiast narracja „sformatowana” pod kątem obaw i resentymentów Polaków przedstawia pracowników z Ukrainy jako ukraińską, nacjonalistyczną piątą kolumnę, stwarzającą zagrożenie dla stabilności Polski i bezpieczeństwa Polaków. Podkreśla się przy tym, że zagrożeniem jest nie tylko, motywowana nacjonalizmem, niechęć Ukraińców do Polski i Polaków, ale także brak programu szczepień na Ukrainie, co w połączeniu ze znaczną liczbą przyjazdów do Polski grozi wybuchem epidemii ${ }^{17}$.

Obok osób poszukujących pracy znaczną grupę obywateli Ukrainy przebywających w Polsce stanowią studenci. Spośród ok. 65 tysięcy obcokrajowców studiujących w Polsce nieco ponad połowę stanowią studenci z Ukrainy ${ }^{18}$. Także wobec tej grupy wysuwane są oskarżenia o „zabieranie miejsc Polakom”, studiowanie na koszt polskich podatników, demoralizację, niechętne adaptowanie się do otoczenia, niechęć do nauki języka polskiego, zamykanie się we własnych środowiskach i wreszcie nacjonalizm (czasem używany wymienne $\mathrm{z}$ faszyzmem). W tym przypadku wyraźnie widać mechanizm dezinformacji - większość wymienionych wyżej zarzutów (poza „zabieraniem miejsc"), choćby biorąc pod uwagę ogólną liczbę ukraińskich studentów w Polsce, można potwierdzić - znajdując ilustrujące je przypadki ${ }^{19}$. Opisując je, dokonując ich generalizacji i projekcji na całą grupę, a potem rozpowszechniając te opinie, można stworzyć przekonujący przekaz.

Co interesujące, kanały i środowiska atakujące Ukrainę często są tymi samymi, które atakują także Stany Zjednoczone Ameryki. To kolejny wątek głęboko zakorzeniony w rosyjskiej narracji adresowanej do elit i społeczeństw Zachodu - narracji zresztą w znacznej mierze skutecznej. Stany Zjednoczone są przedstawiane jako najpoważniejszy czynnik destabilizujący dla światowego bezpieczeństwa, państwo agresywne, siłą narzucające swoją wizję porządku międzynarodowego i bezwzględnie realizujące swoje interesy, łamiące prawo międzynarodowe i nierespektujące żadnych zobowiązań oraz interesów innych państw. Chociaż w Polsce podatność na tego typu opinie tradycyjnie nie jest duża, zwłaszcza na tle niektórych państw Europy Zachodniej, to jednak przebijają się one do świadomości społecznej i są zauważalne ${ }^{20}$. W wątku antyamerykańskim

17 Narracja ta przybrała na sile, kiedy okazało się, że wśród osób, u których jesienią 2018 r. stwierdzono w Polsce odrę, były osoby pochodzące z Ukrainy.

18 Według raportu Studenci zagraniczni w Polsce 2017, opublikowanego przez Fundację Edukacyjną Perspektywy.

19 Np. w 2014 r. grupa ukraińskich studentów w Przemyślu fotografowała się z flagą UPA, a w 2016 r. dwaj młodzi Ukraińcy wykonywali gesty hitlerowskiego pozdrowienia na terenie obozu koncentracyjnego na Majdanku - te i inne tego rodzaju incydenty były szeroko opisywane w polskich mediach i wywoływały falę niechęci.

20 Należy przypuszczać, że jeśli w Europie Środkowo-Wschodniej, w tym w Polsce, zwiększać się będzie obecność, szczególnie militarna, Stanów Zjednoczonych Ameryki, narracja antyamerykańska będzie intensywniejsza. 
pojawia się też antyukraiński - Ukraina jest bowiem przedstawiana jako bezwolne narzędzie w ręku Ameryki, więc tym samym zagrożenie dla pokoju i bezpieczeństwa.

Rosyjskie narracje antypolskie, adresowane do Ukraińców, są mniej finezyjne i rozbudowane, niemniej jednak także nośne. Odnoszą się przede wszystkim do problemów, wynikających z uwarunkowań historycznych. Powraca więc wątek nacjonalistycznych i aroganckich „polskich panów”, z wyższością i pogardą odnoszących się do narodu ukraińskiego ${ }^{21}$. Nie chodzi tu już jednak jedynie o animozje i wzajemne oskarżenia czy urazy. Pojawiają się opinie, że Polacy rzeczywiście zechcą dokonać aneksji/ zaboru części zachodniej Ukrainy, z Lwowem na czele - ma to zdecydowanie inny ciężar polityczny. Narracja tego rodzaju może się stać problemem nie tylko dla stosunków polsko-ukraińskich, ale i dla samej Ukrainy - zaakceptować ją bowiem mogą i środowiska nacjonalistyczne (a więc w zasadzie ex definitione antyrosyjskie), i prorosyjskie - taka oś porozumienia (być może jedyna między tymi środowiskami) stanie się z kolei problemem dla sił prozachodnich i umiarkowanych.

Także zjawisko emigracji zarobkowej do Polski (oraz skala tego zjawiska) jest wykorzystywane $\mathrm{w}$ rosyjskim przekazie. Podkreśla się, że ukraińscy pracownicy w Polsce są wyzyskiwani, źle opłacani i ogólnie traktowani niczym niewolnicy. I znowu, jak $\mathrm{w}$ poprzednich wątkach narracji - przypadki skandalicznego traktowania w Polsce imigrantów z Ukrainy naprawdę miały miejsce - ich nagłaśnianie służy budowaniu i utrwalaniu obrazu rzeczywistości, w której przypadki takie są normą i codziennością, a są motywowane ksenofobią Polaków. Mechanizm budowania narracji, przedstawiającej Polaków jako ukrainofobów (i rusofobów, co oczywiste) jest zazwyczaj podobny wydarzenie w Polsce (np. konflikt ukraińskiego pracownika z polskim pracodawcą) jest przedstawiane $\mathrm{w}$ mediach rosyjskich $\mathrm{z}$ odpowiednim komentarzem, podkreślającym polski nacjonalizm i ksenofobię. W założeniu materiał taki ma trafić na Ukrainę, co zwykle się dzieje i niczym kula śniegowa sprawa urasta do rangi poważnego incydentu, mającego dowodzić niechęci Polaków do Ukraińców (analogiczny mechanizm jest stosowany przy tworzeniu narracji o ukraińskich nacjonalistach) ${ }^{22}$.

\section{Skuteczność narracji antypolskich/antyukraińskich}

Teza, że stosunki polsko-ukraińskie znajdują się w impasie, jest jak najbardziej prawdziwa. I przyczyną tego nie jest tylko aktywność i polityka Rosji, ale przede wszystkim postawa samych Polaków i Ukraińców. Niemniej jednak w interesie Rosji jest, by stosunki te pozostawały złe, zatem będzie ona nadal prowadzić działania zmierzające do pogarszania relacji polsko-ukraińskich, nie tylko w wymiarze symboli i na poziomie dyskursu polityczno-historycznego, ale i na poziomie realnej współpracy: militarnej, ekonomicznej, energetycznej, politycznej.

\footnotetext{
1 I także w tym przypadku przydatne jest generalizowanie i uwypuklanie pewnych zachowań i zdarzeń, jak np. ekscesów pijanych polskich turystów we Lwowie.

22 Por. raport Centrum Analiz Propagandy i Dezinformacji Rosyjska wojna informacyjna przeciwko Polsce, https://capd.pl/pl/raporty/198-rosyjska-wojna-dezinformacyjna-przeciwko-polsce
} 
Działania te przynoszą skutek, ponieważ wywieranie wpływu na stosunki polsko-ukraińskie nie jest nazbyt trudne - $\mathrm{z}$ wielu powodów. Po pierwsze, między Polakami a Ukraińcami istnieje wiele animozji i pretensji zakorzenionych historycznie i nacechowanych emocjonalnie - co pozwala na ich rozgrywanie zgodnie z interesami strony trzeciej (w myśl zasady „dziel i rządź”). Przykładem może być seria incydentów związanych z niszczeniem i bezczeszczeniem miejsc pamięci (pomników, cmentarzy) po obu stronach granicy. Jest wysoce prawdopodobne, że większość bądź nawet wszystkie takie przypadki inspirowane były przez Rosję, ale do powszechnej świadomości dotarł przede wszystkim antypolski i antyukraiński charakter tych incydentów, podgrzewając nastroje ${ }^{23}$. Po drugie, Polacy i Ukraińcy nie rozumieją się nawzajem, co utrudnia konstruktywny dialog. I tak na przykład na Ukrainie nie rozumie się, dlaczego Polaków irytują pomniki i ulice Stiepana Bandery oraz gloryfikowanie OUN-UPA - wszak powodem jest przede wszystkim ich walka przeciwko Rosjanom i Związkowi Radzieckiemu. Tymczasem w Polsce Bandera i UPA są kojarzeni niemal wyłącznie z działaniami przeciw Polakom i państwu polskiemu. Ukraińcy nie rozumieją, dlaczego w Polsce konsekwentnie wraca się do wydarzeń z Wołynia, Polacy natomiast nie rozumieją, że II Rzeczpospolita nie była dla mniejszości narodowych, w tym Ukraińców, państwem zapewniającym im równe prawa obywatelskie i kulturowe. Jedni mówią o „okupacji Lwowa przez Polaków”, drudzy o „polskim Lwowie”. I chociaż te nieprzyjazne wzajemnie nastroje nie dominują w dyskursie publicznym, są jednak na tyle silne, by widocznie oddziaływać na relacje polsko-ukraińskie na różnych poziomach ${ }^{24}$.

Po trzecie, pogarszaniu tych relacji sprzyja polityczna polaryzacja społeczeństw po obu stronach granicy. Zarówno Polacy, jak i Ukraińcy są podzieleni politycznie (choć linie podziałów przebiegają inaczej i są różnie warunkowane), co ułatwia wykorzystywanie sporów i rozbieżności polsko-ukraińskich jako instrumentu walki politycznej i oskarżeń o zaprzaństwo, zdradę interesów narodowych, brak patriotyzmu itp. (szczególnie po stronie polskiej, gdzie relacje polsko-ukraińskie są obciążone intensywniejszym ładunkiem emocjonalnym niż na Ukrainie). W takiej sytuacji polityczna propaganda, odwołująca się do nacechowanych emocjonalnie uprzedzeń, przynosi oczekiwane rezultaty. Szczególnie dotyczy to, po czwarte, radykalnych środowisk, których po obu stronach nie brakuje (rosnąca popularność ugrupowań radykalnych nie jest tendencją widoczną tylko w Polsce czy na Ukrainie, ale w wielu państwach świata). W tym kontekście warto zauważyć, że wpisuje się to w szerszą strategię rosyjskiej polityki informacyjnej, zmierzającą do wspierania obecnych w państwach Zachodu środowisk radykalnych, różnej proweniencji, a w efekcie do destabilizacji społecznej i politycznej.

23 Por. O. Popowycz, Rosyjska wojna informacyjna a relacje polsko-ukraińskie, https://capd.pl/pl/ komentarze/184-komentarz-rosyjska-wojna-informacyjna-a-relacje-polsko-ukrainskie

24 Szerzej na temat wzajemnego niezrozumienia między Polakami a Ukraińcami pisał P. Żurawski vel Grajewski, Specyfika relacji polsko-ukraińskich po 2015 r., „Sprawy Międzynarodowe” 2018, nr 1, s. $61-71$. 
Wreszcie, mimo prób podejmowanych na różnych szczeblach państwa, instytucje zachodnie nie wypracowały jak dotąd skutecznej koncepcji przeciwdziałania rosyjskim działaniom w sferze informacyjnej (co wynika również z braku doświadczenia w tego typu działaniach). Dotyczy to także Polski, przy czym specyfika Polski jako kierunku działania rosyjskiej dezinformacji polega na tym, że otwarta, prorosyjska narracja wciąż ma niewielkie szanse na sukces - z racji żywej w Polsce pamięci o dominacji carskiej Rosji, o wojnie 1920 roku, o agresji 17 września 1939, o terrorze NKWD, o uzależnieniu od Związku Radzieckiego wreszcie - Rosja po dziś dzień postrzegana jest w Polsce jako istotne zagrożenie. O ile więc w państwach, które tego rodzaju doświadczeń historycznych nie miały, rosyjska wizja rzeczywistości może być prezentowana otwarcie bądź niemal otwarcie (co konsekwentnie czyni chociażby RT), o tyle w Polsce są to bardziej zakamuflowane działania, często, jak wspomniano, dokonywane na przykład za pośrednictwem mediów określających się jako "patriotyczne”, „wolne” i „niezależne”. Część prorosyjskich treści jest też w Polsce (nie wspominając o innych państwach zachodnich) tworzona i powielana nie przez źródła inspirowane czy/lub opłacane przez Rosję, ale przez środowiska (głównie polityczne i dziennikarskie), określane tradycyjnie w samej Rosji mianem „pożytecznych idiotów”. Drugi element, decydujący o specyfice Polski w kontekście działań Rosji w sferze informacyjnej, odnosi się właśnie do stosunków polsko-ukraińskich. Ze względu na ich skomplikowany charakter relatywnie łatwo jest $\mathrm{w}$ taki sposób skonstruować narrację na temat Polski i Ukrainy (z Rosją w tle), żeby podsycać uprzedzenia antyukraińskie, a jednocześnie starać się stworzyć pozytywny wizerunek Rosji ${ }^{25}$.

Ogólną konkluzję, nasuwającą się w odniesieniu do działań Rosji w sferze informacyjnej, w tym działań w kontekście stosunków polsko-ukraińskich, można sformułować zwięźle: Rosja w „wojnie informacyjnej” ma przewagę i trudno prognozować, czy i kiedy sytuacja ta ulegnie zmianie. Sytuacja taka występuje zarówno w szerszym wymiarze, gdy mowa o konfrontacji w sferze informacyjnej między Rosją a Zachodem, jak i w węższym, odnoszącym się do oddziaływań informacyjnych w kontekście stosunków polsko-ukraińskich. W tym pierwszym wymiarze przewagę Rosji daje opisywana wcześniej asymetria - w przeciwieństwie do Zachodu nie ograniczają jej w działaniach demokratyczne

25 Warto wspomnieć o jeszcze jednym instrumencie „miękkiej siły”, służącym także wpływaniu na świadomość społeczeństw - to kultura, która obecnie stała się towarem, ale jest też używana jako instrument oddziaływania. W przypadku Rosji ważnym instrumentem wpływu kulturowego jest kino, w tym kino wojenne, odgrywające ważną rolę w tworzeniu i konsolidowaniu mitów narodowych. Przekaz bojewików jest głównie kierowany do odbiorcy wewnętrznego, ale trafia także na zewnątrz. Przykładem ewolucji tego przekazu jest film Jedynka (Единичка) w reżyserii Kiryła Bielewicza. Wyprodukowany w 2015 r. film ukazuje, po raz kolejny w tego rodzaju kinie radzieckim/rosyjskim, Armię Czerwoną wyzwalającą Polskę od faszyzmu (w 1944 r.). Jednak tym razem czerwonoarmiści, mimo różnic i kłótni ideologicznych, walczą ramię w ramię z... polskimi partyzantami w Armii Krajowej. A przeciwnikiem są diaboliczni Niemcy oraz ich wierni i barbarzyńscy sojusznicy - Ukraińcy. To istotna zmiana przekazu - do tej pory w rosyjskich filmach wojennych ani polscy partyzanci, ani Ukraińcy praktycznie się nie pojawiali (ewentualnie na trzecim planie, zwykle jako hitlerowscy kolaboranci). 
zasady ustrojowe, a zamiast wolności słowa jest daleko posunięta kontrola informacji. Jeśli chodzi o drugi wymiar stosunków polsko-ukraińskich, w działaniach w infosferze z powodzeniem jest wykorzystywany potencjał konfliktu, jakim obciążone są, z racji uwarunkowań historycznych, te stosunki (do czego zresztą Rosja przyczyniała się także w przeszłości - konflikt polsko-ukraiński był i jest bowiem w jej interesie). W efekcie tak w Polsce, jak i w innych państwach Zachodu narracja prorosyjska jest swobodnie powielana i przekazywana - zgodnie z demokratyczną zasadą wolności słowa i sumienia. Pozornie nie różni się to od każdej innej narracji, występującej w globalnej przestrzeni informacyjnej. W tym jednak przypadku jest to narracja używana jako instrument świadomej destabilizacji i czynnik zmiany świadomości społecznej.

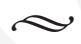

Streszczenie: Celem artykułu jest zwięzłe przedstawienie roli polityki informacyjnej Rosji w odniesieniu do stosunków polsko-ukraińskich. Działania w sferze informacyjnej są obecnie jednym z najważniejszych instrumentów rosyjskich wpływów, wykorzystywanych (zgodnie z zasadą "dziel i rządź") w realizacji strategii, zmierzającej do odbudowania przez Rosję pozycji mocarstwa. W kontekście stosunków polsko-ukraińskich celem tych działań jest pogłębianie animozji między Polakami a Ukraińcami, a w szerszej perspektywie zatrzymanie Ukrainy w rosyjskiej „strefie wpływów” i umacnianie nastrojów prorosyjskich.

Stowa kluczowe: Rosja, Polska, Ukraina, polityka informacyjna

\section{Polish-Ukrainian Relations in Russian Federation's (Dis)Information Policy}

Abstract: The aim of the paper is a brief description of Russian information policy in the context of Polish-Ukrainian relations. Activities in infosphere are one of the most important tools of Russian influence and they are used (in accordance with 'divide et impera' rule) to implement strategy aiming at restoration Russian imperial position. When it comes to Polish-Ukrainian relations the main objective of the activities is to provoke and deepen antagonisms between Poles and Ukrainians. In a broader perspective it is aimed at keeping Ukraine in the 'Russian sphere of influence' and at enhancing pro-Russian attitudes.

Keywords: Russia, Poland, Ukraine, information policy

\section{Польско-украинские отношения В (дез) информационной политике Российской Федерации}

Аннотация: Цель исследования - кратко представить роль информационной политики России в отношении польско-украинских отношений. Деятельность в сфере информации в настоящее время является одним из важнейших инструментов российского влияния, используемым (в соответствии с принципом «разделяй и властвуй») при реализации стратегии, направленной на восстановление в России позиции сверхдержавы. В контексте польско-украинских отношений цель 
этих действий состоит в том, чтобы углубить вражду между поляками и украинцами и, в более широком плане, оставить Украину в российской "сфере влияния" и усилить пророссийские настроения.

Ключевые слова: Россия, Польша, Украина, информационная политика

\section{Bibliografia}

Castells M., Społeczeństwo sieci, Warszawa 2007.

Darczewska J., Anatomia rosyjskiej wojny informacyjnej. Operacja krymska - studium przypadku, „Punkt Widzenia OSW" 2014, nr 42

Giles K., Handbook of Russian information warfare, Rome 2016.

https://apostrophe.ua/article/society/culture/2017-04-18/oksana-zabujko-segodnya-ne-nujno-bombit-goroda-dostatochno-razbombit-mozgi/11737

Jaroszewicz M., Migracje z Ukrainy do Polski. Stabilizacja trendu, Warszawa 2018.

Paniuszkin W., Zygar M., Gazprom. Rosyjska broń, Warszawa 2008.

Pariser E., The Filter Bubble: What The Internet is Hiding from You, London 2012.

Popowycz 0., Rosyjska wojna informacyjna a relacje polsko-ukraińskie, https://capd.pl/pl/komentarze/184-komentarz-rosyjska-wojna-informacyjna-a-relacje-polsko-ukrainskie

Raport Centrum Analiz Propagandy i Dezinformacji Rosyjska wojna informacyjna przeciwko Polsce, https://capd.pl/pl/raporty/198-rosyjska-wojna-dezinformacyjna-przeciwko-polsce

Smagliy K., Hybrid Analytica: Pro-Kremlin Expert Propaganda in Moscow, Europe and the US, Institute of Modern Russia Research Paper, October 2018, New York.

Sykulski L., Rosyjska koncepcja wojen buntowniczych Jewgienija Messnera, „Przegląd Geopolityczny” 2015, t. 11.

Włodkowska-Bagan A., Kultura strategiczna Rosji, „Sprawy Międzynarodowe” 2017, nr 3, s. 36-47.

Włodkowska-Bagan A., Polityka Rosji na obszarze poradzieckim, "Wschodni Rocznik Humanistyczny” 2017 , t. 14, nr 3, s. 66-68.

Żurawski vel Grajewski P., Specyfika relacji polsko-ukraińskich po 2015 r., "Sprawy Międzynarodowe” 2018, nr 1, s. 61-71.

Магда Є., Гібридна війна. Вижити і перемогти, Харків 2015. 